THE STRAIGHT BILL OF LADING:

\title{
DEVELOPMENT OF PRESENTATION RULE IN MAINLAND CHINA AND HONG KONG
}

\author{
Liang Zhao
}

TABLE OF CONTENT

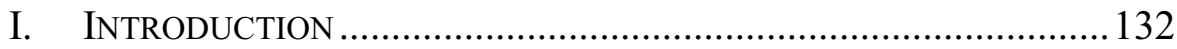

II . THE PRESENTATION RULE IN CHINA ...................................... 133

A. Judicial position before and after the Maritime Code..... 133

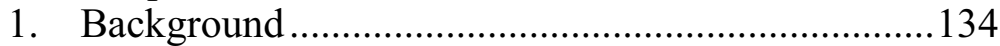

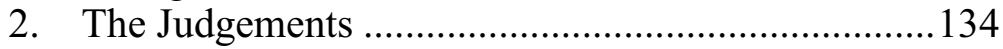

3. Comments ...........................................................136

B. The straight bill of lading in the Maritime Code ............136

C. Further development in judicial practice ....................... 137

D. The right of control in the Contract Law .......................137

E. The application of right of control in carriage of goods by sea............................................................ 138

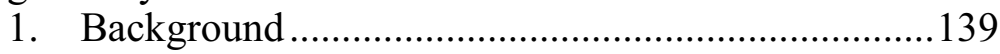

2. The Judgements ................................................139

3. Comments ........................................................... 140

F. Judiciary interpretation under the right of control .......... 140

III. HONG KONG'S POSITION ........................................................ 142

A. Background of the presentation rule ............................. 142

B. The presentation rule in Carewins v Bright Fortune....... 143

IV. THE ROTTERDAM RULES' PRESENTATION RULE AND

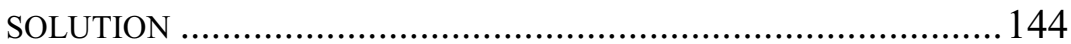

A. The presentation rule in the Rotterdam Rules ............... 145

B. Comment on the presentation rule .............................. 146

C. Solution for China's problem ...................................... 146

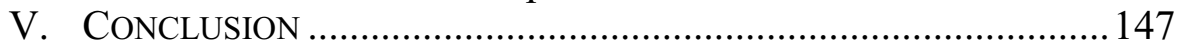


THE STRAIGHT BILL OF LADING:

\title{
DEVELOPMENT OF PRESENTATION RULE IN MAINLAND CHINA AND HONG KONG
}

\author{
Liang Zhao*
}

\section{Abstract}

The presentation rule of the straight bill of lading developed in different approaches in the jurisdictions of Mainland China and Hong Kong. In the Mainland, the carrier shall not be liable for the delivery of goods without the presentation of the straight bill if he does so according to the shipper's instruction and the consignee has no cause of action against the carrier for such delivery. Conversely, Hong Kong followed the strict presentation rule confirmed by the precedents of Singapore and UK in which the straight bill of lading is required to be presented for the delivery of goods. These developments indicate the disharmony of the presentation rule of the straight bill of lading. The recently adopted Rotterdam Rules may play an important role for the unification of the presentation rule.

\section{INTRODUCTION}

In Mainland China, after the adoption and the promulgation of the Maritime Code of the People's Republic of China ("the Maritime Code"), which became effective as of July 1, 1993, the straight bill of lading, although it is non-negotiable, is considered a document of title. On the other hand, Article 308 of the Contract Law of the People's Republic of China ("the Contract Law") which took effect as of the $1^{\text {st }}$ of October 1999 confers on the shipper the right of control so as to vary the delivery of goods. In "Supreme People's Court Rules on the Law Application in the Trial of Cases of Delivery of Goods without Original Bill of Lading" (the No.1 Judicial Interpretation of 2009), the Supreme Peoples' Court of the People's

\footnotetext{
* PhD candidate in maritime law and trade law, Faculty of Law, The University of Hong Kong.
} 
Republic of China ("the Supreme Court") interpreted that the carrier is not liable for the delivery of goods without the presentation of straight bills of lading subject to the right of control exercised by the shipper.

Contrary to China's approach, the Court of Final Appeal of Hong Kong upheld the decision in Carewins Development (China) Ltd. v. Bright Fortune Shipping Ltd. (Carewins v Bright Fortune) ${ }^{2}$ in 2009 that goods must be delivered to the consignee only against the presentation of straight bills of lading. This decision kept the Hong Kong law in accord with that of other common law jurisdictions, e.g. England and Singapore.

The right of control in the Contract Law is a typical legal right in civil law, while such right does not exist in common law. This different development may be polarised into two opposite approaches for the presentation rule of the straight bill of lading in Mainland China and Hong Kong jurisdictions. The United Nations Convention on Contracts for the International Carriage of Goods Wholly or Partly by Sea (A/RES/63/122), namely "the Rotterdam Rules", aims to harmonize the common and civil law approaches to the presentation rule of the straight bill of lading.

\section{THE PRESENTATION RULE IN CHINA}

\section{A. Judicial position before and after the Maritime Code}

The leading case concerning the straight bill of lading in respect of the presentation rule and the carrier's liability is the decision in Guangdong Electronics Ltd. v. China Merchants Godown, Wharf \& Transport Co., Ltd. and others (Guangdong Ltd. v. China Merchants). ${ }^{3}$ In this case, all the parties to the contract of carriage and the contract of sale of goods involved in the dispute of the delivery of goods under the straight bill of lading. The Supreme Court finally confirmed the presentation rule and held that the carrier was liable for the breach of the presentation rule.

\footnotetext{
${ }^{1}$ Zuigao Renmin Fayuan Guanyu Shenli Wuzhengben Tidan Jiaofu Huowu Anjian Shiyong Falü Ruogan Wenti de Guiding (最高人民法院关于审理无正本提单交付货物案件适用法律若干问题的 规定) [Supreme People's Court Rules on the Law Application in the Trial of Cases of Delivery of Goods without Original Bill of Lading] (promulgated by Sup. People's Ct., Feb. 26, 2009, effective Mar. 5, 2009) 2009 Sup. PeOPLE's Ct. GAZ. 23 (China).

${ }^{2}$ Carewins Development (China) Ltd.. v Bright Fortune Shipping Ltd.., [2009] 3 H.K.L.R.D. 409 (C.F.A.) (H.K.).

${ }^{3}$ Yuehai Gongsi Yu Cangma Gongsi, Tefa Gongsi deng Haishang Huowu Yunshu Wudan Fanghuo Tihuo Daili Fanghuo Jiufen Zaishen An (粤海公司与仓码公司、特发公司等海上货物运输 无单放货、提货、代理放货纠纷再审案)[Guangdong Electronics Ltd.. v. China Merchants Godown, Wharf \& Transport Co., Ltd.. and others], 1997 Sup. People's CT. GAZ. 32, 32-35 (Sup. People's Ct. 1996).
} 
1. Background

On January 3 and February 21, 1989, the seller, Guangdong Electronics Ltd. (Guangdong Ltd.), entered into two contracts of sale with the buyer, China Port Development Ltd. (China Port). The goods consisted of ten thousand $(10,000)$ sets of refrigerator parts. On January 26 and February 21, they had been shipped from Hong Kong to Shenzhen in two instalments by the carrier, China Merchants Godown, Wharf \& Transport Co., Ltd. (China Merchants). China Merchants accordingly issued to Guangdong Ltd. four sets of straight bills of lading on which the shipper was Guangdong Ltd. on behalf of China Port and the consignee was Guangdong Ltd.. After the arrival of the goods, Guangdong Ltd. refused to transfer the straight bills of lading to China Port because China Port had not paid for the goods. In the end, Shenzhen Special Economic Zone Development Co. (Shenzhen Development) issued a guarantee for China Port and the shipping agency of China Merchants, and China Ocean Shipping Agency, Shekou Branch (Shekou Agency) accordingly released a copy of the straight bills of lading to Shenzhen Development for the clearance of goods. China Port finally obtained the first instalment of five thousand $(5,000)$ sets of goods. As to another instalment of goods, Shekou Agency released another copy of the straight bills of lading to Zhuhai Island Development \& Trading General Co. (Zhuhai Island) for the clearance of goods. However, due to the non-payment for the customs duties, those goods were auctioned off by the customs and the court after long-term storage in the warehouse.

Thereafter, Guangdong Ltd. claimed against China Merchants in the Guangzhou Maritime Court for the loss caused by the delivery of the goods without the presentation of original bills of lading. Afterwards, China Merchants raised a similar claim against Shekou Agency, China Port, Shenzhen Development and Zhuhai Island in the same Court. Because the same facts and the same claims object, the two cases were combined and heard together in the Guangzhou Maritime Court.

\section{The Judgements}

In the first instance, the Guangzhou Maritime Court followed the traditional shipping practice that goods should be delivered against the presentation of original bills of lading. This dispute was considered as a tortuous act by the Court. It was held that Guangdong Ltd., as the holder of the straight bills of lading and the consignee named in the bills, was entitled to the delivery of the goods and, when the goods were delivered to others without the presentation of the original bills, had the title to sue against the tortfeasor. China Port was the tortfeasor who should be liable for 
the loss of the first instalment of the goods because it actually obtained those goods. Shekou Agency and Shenzhen Development assisted China Port to obtain the goods and therefore bore joint liability for such loss. China Merchants, as the carrier, was not involved in the tortious act and therefore was not liable for the loss in conversion. As to the second instalment of the goods, the Court held that Zhuhai Island had not obtained the second instalment of the goods and therefore it was not liable for the loss of those goods. Guangdong Ltd. was responsible for the auction sale because it failed to arrange the clearance and the delivery of the goods in time. Guangdong Ltd. and Shekou Agency appealed to the Guangdong High People's Court.

The Guangdong High People's Court upheld that Guangdong Ltd.'s right to take the delivery and interest in the first instalment of the goods should be protected, while the claim for the loss of the second instalment of the goods was denied due to its failure to fulfil the taking of the delivery of those goods. Meanwhile, Zhuhai Island applied to customs for the second instalment of the goods and thus made the delivery of them to Guangdong Ltd. impossible. Therefore, Zhuhai Island was liable for the loss of those goods as well. The High Court disagreed with the liability of China Port and held that China Port was not the tortfeasor. The real tortfeasor was Shenzhen Development who applied to customs so as to deliver the goods without the presentation of the original bills of lading. Both China Merchants as the principal and Shekou Agency should undertake the joint liability for the loss of the first instalment of the goods. China Merchants, Shenzhen Development and Shekou Agency filed grievances to the Supreme Court.

During the retrial by the Supreme Court, the Maritime Code of the PRC took effect. The Supreme Court referred to the Maritime Code and clarified the law out of chaos in the foregoing judgments. The Court held that this case was a contractual dispute instead of a tortious one. The carrier's contractual obligation was to deliver the goods to the named consignee in the straight bills of lading. Shekou Agency's delivery of the goods without the presentation of the original bills breached the presentation rule; China Merchants as the principal should be liable for the loss caused. Therefore, China Merchants as the carrier was in breach of the contract evidenced by the straight bills of lading and should be liable for the loss of Guangdong Ltd. caused by such breach. In addition, Shekou Agency, Shenzhen Development and China Port accordingly were liable to the loss of China Merchants. As to the second instalment of the goods, Guangdong Ltd. was responsible for its own fault for failing to take delivery of them. 
3. Comments

Guangdong Ltd. v. China Merchants is a watershed case in respect of the straight bills of lading in the judicial practice of China. Not only has the presentation rule of the straight bills of lading been confirmed by the Supreme Court, but the nature of the dispute concerning the delivery of goods without presentation of the original straight bills has been clarified. Before the retrial judgment of the Supreme Court, the carrier was not liable for his breach of the presentation rule or just undertook the joint liability. The final judgment of this case corrected the contractual obligation of the carrier to deliver goods against the presentation of the straight bills of lading. Other parties including the person who has actually obtained goods may only undertake joint liability for the loss the consignee named in the straight bills of lading.

\section{B. The straight bill of lading in the Maritime Code}

It was the Maritime Code that provided the legal basis for the retrial judgment of the Supreme Court in Guangdong Ltd. v. China Merchants. In the Maritime Code, a bill of lading is a document recognised as evidence of the contract of carriage of goods by sea and the taking or loading of the goods by the carrier. ${ }^{4}$ The relationship between the carrier and the holder of a bill of lading with respect to their rights and obligations shall be defined by the clauses of the bill of lading. ${ }^{5}$ A bill of lading is also a document of title based on which the carrier undertakes to deliver the goods against the presentation of it. A provision in a bill of lading stating that the goods are to be delivered to the order of a named person, or to order, or to bearer, constitutes such an undertaking. ${ }^{6}$ Because this does not refer to the delivery to the consignee named on the straight bill of lading, it was understood that such an undertaking under a bill of lading did not apply to the straight bill of lading. In other words, the goods under a straight bill of lading may be delivered without the presentation of original straight bills of lading. The bill of lading in the Maritime Code is categorised into three types, that is, a straight bill of lading, an order bill of lading and a bearer bill of lading. ${ }^{7}$ Therefore, the straight bill of lading is still required to be presented

\footnotetext{
${ }^{4}$ Haishang Fa (海商法) [Maritime Code] (promulgated by the Standing Comm. Nat'l People's Cong., Nov. 7, 1992, effective July 1, 1993), art. 71, 2009 Falü Quanshu 2-221, 2-227 ， translated in 4 P.R.C. Laws 411 (China).

${ }_{5}^{5}$ Id. art. 78, If 1.

${ }^{6}$ See supra note 4.

${ }^{7}$ Article 79 states that the negotiability of a bill of lading shall be governed by the following provisions: (1) A straight bill of lading is not negotiable; (2) An order bill of lading may be negotiated with endorsement to order or endorsement in blank; (3) A bearer bill of lading is negotiable without endorsement.
} 
for the delivery of goods. Guangdong Ltd. $v$ China Merchants confirmed this opinion in judicial practice.

\section{Further development in judicial practice}

The presentation rule of the straight bill of lading became strict in China's judicial practice. If the carrier delivers goods without the presentation of the original straight bills of lading, not only the consignee in Guangdong Ltd. v. China Merchants, but also the shipper may claim against the carrier for the breach of the presentation rule. In Orient Overseas Container Line v. Qingdao Haishen Food Co., Ltd., the goods were delivered to the consignee named in the straight bills of lading. However, the consignee did not pay for the goods and the shipper still held the straight bills of lading when the goods were delivered. The shipper raised a claim against the carrier for his loss of payment for the goods. The court of the first instance held that the carrier's delivery of goods was in breach of his obligation to deliver goods against the presentation of the original straight bills of lading. Although the goods were delivered to the correct consignee, it caused the loss of protection of the payment for the goods and the loss of the control of the goods by the shipper. Therefore, the carrier was liable for the loss of the payment for the goods of the shipper. The carrier appealed against the presentation rule in this decision. The High Court and the Supreme Court upheld this decision and confirmed that the delivery of goods must be against the presentation of the original straight bills of lading.

\section{The right of control in the Contract Law}

The right of control in the Contract Law challenged the traditional presentation rule in China. Article 308 of the Contract Law 1999 provides the right of control for general contract of carriage of goods. It states that before the delivery of goods to the consignee by the carrier, the shipper may request the carrier to stop the goods in transit, return the goods, change the place of destination or deliver the goods to another consignee, but shall indemnify the carrier for the loss caused. ${ }^{9} \quad$ This article itself does not concern the issue of the bill of lading in shipping practice. It is well understood that when a bill of lading is issued and negotiated to a third party, the carrier is

\footnotetext{
${ }^{8}$ Dongfang Haiwai Huogui Hangyun Youxian Gongsi Su Qingdao Haishen Shipin Youxian Gongsi (东方海外货柜航运有限公司诉青岛海神食品有限公司) [Orient Overseas Container Line v. Qingdao Haishen Food Co. Ltd..], (Sup. People's Ct. Apr. 6, 2004) (Chinalawinfo).

9 Hetong Fa (合同法)[Contract Law](promulgated by the Standing Comm. Nat' 1 People' s Cong., Mar. 15, 1999, effective Mar. 15, 1999) 1999 STANDING COMM. NAT' L PEOPLE' S CONG. GAZ. (China).
} 
bound to follow the practice of bills of lading by delivering the goods to the lawful holder of the bill. If the shipper instructs the carrier not to deliver the goods to the lawful holder of the bill, the carrier may be liable to the holder of the bill for the damages caused by compliance with the shipper's instructions. The carrier, after compensating the loss suffered by the holder of the bill, may then recover his loss against the shipper in accordance with the provision of the right of control. ${ }^{1}$

As to the application of the law, the Contract Law provides that if there are provisions as otherwise stipulated in respect of contracts in other laws, such provisions shall be followed. ${ }^{11}$ It means that the Maritime Code has the priority and shall prevail as a special law for the contract of carriage of goods by sea. In judicial practice, the concept of the right of control was hardly accepted for the carriage of goods by sea. In Zhongda Textiles Co., Ltd. v. " $K$ ”' Line (China) Ltd..., ${ }^{12}$ the court of the first instance refused the application of the right of control because there was no special condition in the Contract Law for the shipper's right to modify the contract of carriage of goods by sea. The cargo interests appealed. The High Court upheld that the Maritime Code should apply to the dispute of the carriage of goods by sea and the Maritime Code does not confer any right on the shipper to unilaterally modify the contract. In Mingxing Co., Ltd. v. Wanhai Shipping Co., Ltd., ${ }^{13}$ the court pointed out that the Contract Law was a general law for all kinds of carriage of goods and thus did not contain strict and specific provisions like those found in the Maritime Code for the carriage of goods by sea. Therefore, the carrier was not legally obliged to comply with shipper's request by returning the goods under Article 308 in the Contract Law. Both of the cases indicate the reluctance of the courts to apply the right of control in the carriage of goods by sea.

\section{E. The application of right of control in carriage of goods by sea}

It is the decision in Heilongjiang Export and Import Co., Ltd. v. Brilliant Logistics Group Inc. and others (Heilongjiang Ltd. v.

\footnotetext{
${ }^{10} \mathrm{Si}$ Yuzhuo (司玉玩) et al., Haishang Fa (海商法) [Maritime Law] 121-22 (2d ed. 2007).

${ }^{11}$ Hetong Fa (合同法)[Contract Law](promulgated by the Standing Comm. Nat'l People's Cong., Mar. 15, 1999, effective Mar. 15, 1999) 1999 STANDING CoMM. NAT'L PEOPLE's Cong. GaZ. (China).

${ }^{12}$ Zhejiang Zhongda Fangzhipin Youxian Gongsi Yin Haishang Huowu Yunshu Hetong Tuiyun Jiufen Shangsu An (浙江中大纺织品有限公司因海上货物运输合同退运纠纷上诉一案) [Zhongda Textiles Co., Ltd.. v. "K" Line (China) Ltd..], (Shanghai High Ct., Sep. 22, 2003) available at http://www.ccmt.org.cn/showws.php?id=2378.

${ }_{13}$ Zhejiang Zhongda Fangzhipin Youxian Gongsi Yin Haishang Huowu Yunshu Hetong Tuiyun Jiufen An (浙江中大纺织品有限公司因海上货物运输合同退运纠纷案) [Zhongda Textiles Co., Ltd.. v. "K" Line (China) Ltd..],(Shanghai Maritime Ct., Nov. 24, 2002).
} 
Brilliant Logistics $)^{14}$ the application of the right of control in the carriage of goods by sea was clarified. The court held that the right of control applied only in the carriage of goods by sea where the straight bill of lading had been issued.

1. Background

On October 9, 1999, Heilongjiang Export and Import Co., Ltd. (Heilongjiang Ltd.) contracted with Brilliant Logistics Group Inc. (Brilliant Logistics) for the carriage of goods to Baltimore. On October 18, Brilliant Logistics issued a set of order bills of lading. Because of a dispute in a sale contract with the consignee who had held two of the original bills, on November 29, Heilongjiang Ltd. instructed Brilliant Logistics not to deliver the goods without the full set of the bills of lading, or without his express consent in writing. Brilliant Logistics accepted such an instruction. On December 16, Heilongjiang Ltd. instructed that the goods were to be carried to Los Angeles. On January 11, 2000, Heilongjiang Ltd. was notified that the goods had been delivered against the presentation of two original bills of lading, which was against Heilongjiang Ltd.'s instruction. In the Guangzhou Maritime Court, Heilongjiang Ltd., holding one of the original bills of lading, claimed against Brilliant Logistics for damages for the loss of the goods.

\section{The judgements}

The court of the first instance held that a bill of lading was a document against which the carrier promised to deliver the goods. Brilliant Logistics legally delivered the goods against the surrender of two of the original bills of lading. Therefore, after the delivery of the goods, the remaining bill of lading held by Heilongjiang Ltd. became void, and Heilongjiang Ltd.'s claim was rejected. Heilongjiang Ltd. appealed, asserting that according to Article 308 of the Contract Law, it was entitled to require Brilliant Logistics to follow its instruction, and Brilliant Logistics should be liable when it failed to do so. In the second instance, the Guangdong High

\footnotetext{
${ }^{14}$ Heilongjiang Jinchukou Gongsi su Shantou Yuedong Guoji Huoyun Daili Youxian Gongsi \& Jiangsu Huanqiu Guoji Huoyun Gongsi Shenzhen Fengongsi \& Bolian Guoji Huoyun Gongsi Haishang Huowu Yunshu Hetong Huowu Jiaofu Jiufen An (黑龙江省进出口公司诉汕头粤东国际货运代理有 限公司、江苏环球国际货运公司深圳分公司、博联国际货运公司海上货物运输合同货物交付纠 纷案) [Heilongjiang Export and Import Co., Ltd.. v. Brilliant Logistics Group Inc. and others]( Guangdong High Ct., Dec. 3, 2002).

${ }^{15}$ Heilongjiang Jinchukou Gongsi su Shantou Yuedong Guoji Huoyun Daili Youxian Gongsi \& Jiangsu Huanqiu Guoji Huoyun Gongsi Shenzhen Fengongsi \& Bolian Guoji Huoyun Gongsi Haishang Huowu Yunshu Hetong Huowu Jiaofu Jiufen An (黑龙江省进出口公司诉汕头粤东国际货运代理有 限公司、江苏环球国际货运公司深圳分公司、博联国际货运公司海上货物运输合同货物交付纠 纷案) [Heilongjiang Export and Import Co., Ltd.. v. Brilliant Logistics Group Inc. and others] (Guangzhou Maritime Ct., Nov. 28, 2001), available at http://www.ccmt.org.cn/showws.php?id=867.
} 
People's Court upheld that Brilliant Logistics legally delivered the goods against the surrender of the bills of lading and thus was not liable to Heilongjiang Ltd.. As to Article 308 of the Contract Law which confers the right on the shipper to dispose of the goods before delivering them to the consignee, the High Court construed that the consignee in this Article meant the consignee nominated in the straight bill of lading only. Other consignees as ordered or as the holder of the order or bearer bills of lading were not the consignee referred to in Article 308. In other words, the right of control applied only to the dispute concerning the straight bill of lading. In this case, the order bills of lading were issued. Heilongjiang Ltd. was not entitled to give instructions to modify the contract of carriage. The practice of bills of lading must be respected for its protection of bona fides third party. The appeal was accordingly dismissed.

\section{Comments}

This case indicates that even though the right of control is considered, it is not unconditional to apply it to the carriage of goods by sea. The courts recognised the shipper's right under Article 308, but pointed out that the shipper did not have the right of control in any circumstance. Shipper's request for modification of the contract of carriage must be restricted in certain sea carriage contracts. Where negotiable bills of lading have been issued, once such bills are negotiated from the shipper to another person, the shipper loses the rights under the bills and accordingly is not entitled to the right of control. Therefore, the shipper is no longer entitled to instruct the carrier to stop the goods in transit, return the goods, change the place of destination or change the consignee if the shipper does not hold the full set of bills of lading. ${ }^{16}$ The contribution of this case is to clarify that the right of control applies to the carriage of goods by sea only when the straight bill of lading is issued. However, the court has not provided the legal basis or legal reasoning for such understanding.

\section{F. Judiciary interpretation under the right of control}

Although the statement concerning the straight bills of lading in Heilongjiang Ltd. v. Brilliant Logistics is obiter dictum by judges in the Guangdong High Court, this understanding was accepted by the Supreme Court. In the No.1 Judicial Interpretation of 2009 promulgated by the Supreme Court, Provision 9 states that where a

${ }^{16}$ Lü Botao (吕伯涛) et al., Haishi Anli Jingxuan Jingxi (海事案例精选精析) [MARITIME TRADE CASES AND COMMENTS] 343-44 (2004). 
straight bill of lading has been issued, if the carrier follows the shipper's instruction to stop the goods in transit, return the goods, change the place of destination or deliver the goods to another person other than the consignee, then the nominated consignee holding the straight bill of lading claims against the carrier concerning the liability due to the delivery of goods without presentation of the original straight bill of lading, such claim shall be rejected by people's courts.

This provision changes the aforesaid presentation rule. It means that if the carrier refuses to deliver goods to the named consignee in a straight bill of lading or delivers goods to a person other than the named consignee according to the shipper's instruction, the named consignee cannot claim against the carrier that the carrier is liable for the non-delivery or the delivery without the presentation of the original straight bill of lading. Cargo interests may have to abandon the usage of the straight bill of lading so as to secure the delivery of goods or the title to sue against the carrier. A senior judge who was in charge of drafting the Interpretation in the Supreme Court provided the explanation of this Provision. ${ }^{17}$ He pointed out that the straight bill of lading is a document of title, however, it is nonnegotiable. The property right of goods embodied by the straight bill of lading is thus restricted. Therefore, the right of the consignee named in a straight bill of lading is subordinate to that of the shipper of the straight bill of lading. Because of the subordinate position of the named consignee, the shipper of the straight bill of lading has the right of control as provided in the Contract Law. Although this provision was explained, it is hard to understand the interference with the presentation rule under the straight bill of lading. What can be clarified is that the straight bill of lading continues to be a document of title and the previous presentation rule continues to bind the carrier unless the carrier's breach of the presentation rule is subject to the shipper's instruction under the right of control where the straight bill of lading is issued.

\footnotetext{
${ }^{17}$ Liu Shoujie (刘寿杰), Jiedu “Zuigao Renmin Fayuan Guanyu Shenli Wu Zhengben Tidan Jiaofu Huowu Anjian Shiyong Falü Ruogan Wenti de Guiding” (解读《最高人民法院关于审理无正本提单 交付货物案件适用法律若干问题的规定》) [Annotation for the "Several Provisions of the Supreme People's Court on Application of Law f or Trial of Disputes over Delivery of Goods Without Production of Original Bill of Lading”], ZHONGGUO HAISHANG FA NiANKAN (中国海商法年刊) [Ann. China Mar. L.], Sept. 2009, at 21, 24-26.
} 


\section{HONG KONG’S POSITION}

\section{A. Background of the presentation rule}

The sources of the law of the carriage of goods by sea in Hong Kong include the legislation (i.e. ordinances), case law and international conventions. "Carriage of Goods by Sea Ordinance" provides the application of the Hague-Visby Rules in Hong Kong. ${ }^{19}$ In the Rules the contract of carriage applies only to contracts covered by a bill of lading or any similar document of title. ${ }^{20}$ On the other hand, "Bills of Lading and Analogous Shipping Documents Ordinance" applies to the shipping documents including bills of lading, sea waybills and ship's delivery orders. ${ }^{21}$ It seems unclear in which category the straight bill of lading should be. This Ordinance provides as well that a bill of lading does not include a document which is incapable of transfer either by endorsement or, as a bearer bill, by delivery without endorsement. ${ }^{22}$ Conversely, the straight bill of lading matches the sea waybill prescribed in this Ordinance. A sea waybill is not a bill of lading but a receipt for goods as contains or evidences a contract for the carriage of goods by sea, and identifies the person to whom delivery of the goods is to be made by the carrier in accordance with that contract. ${ }^{23}$ Nevertheless, the provisions of this Ordinance shall have effect without prejudice to the application of the Hague-Visby Rules. ${ }^{24}$ There is no concept of the right of control in the law of the carriage of goods by sea in Hong Kong.

Case law means the decisions adopted by the courts in Hong Kong. Meanwhile the decisions from other common law jurisdictions, such as England, Canada, Singapore and etc., may well continue to be persuasive in Hong Kong. ${ }^{25}$ As to the presentation rule, case law provides the detailed answer. In 2000, the decision

\footnotetext{
18 Felix W H Chan et al., Shipping AND Logistics LAw: Principles AND Practice IN Hong KONG 3-4 (2002).

${ }^{19}$ Hong Kong Carriage of Goods by Sea Ordinance, (1994) Cap. 462, § 3.

${ }^{20}$ International Convention for the Unification of Certain Rules of Law Relating to Bills of Lading $\S$ I(b), Aug.25, 1924, 51 Stat. 233, 120 L.N.T.S. 155 [hereinafter Hague Rules]. The Hague-Visby Rules are the Hague Rules as amended by the Visby Protocol. Protocol to Amend the International Convention for the Unification of Certain Rules of Law Relating to Bills of Lading, Feb. 23, 1968, 1412 U.N.T.S. 128. The Hague-Visby Rules were further amended by the Special Drawing Right (SDR) Protocol. Protocol Amending the International Convention for the Unification of Certain Rules of Law Relating to Bills of Lading, Dec. 21, 1979, 1984 Gr. Brit. T.S. No. 28 [hereinafter Hague-Visby Rules]. $3(1)$.

21 Hong Kong Bills of Lading and Analogous Shipping Documents Ordinance, (1994) Cap. 440, $\$$

${ }^{22}$ Id. $\S 3(2)$

${ }^{23} I d . \oint 3(3)$

24 Id. $\$ 8$.

25 See supra note 17 , at 11 .
} 
of the Court of First Instance of the Hong Kong High Court in The $B_{r j j^{26}}$ set up a presentation rule of the straight bill of lading. It was held that under a straight bill of lading a carrier was entitled and bound to deliver the goods to the originally named consignee without the presentation of the straight bill of lading. However, in 2002, the decision of the Singapore Court of Appeal in Voss v. APL Co. Pte. Ltd. ${ }^{27}$ expressed a different approach to the presentation rule under a straight bill of lading. The Court held that presentation was a prerequisite to obtaining delivery of goods. And in respect of a straight bill of lading the carrier should only deliver the goods against its presentation. The UK House of Lords accepted this understanding in J. I. Macwilliam Co. Inc. v. Mediterranean Shipping Co. S.A., ("The Rafaela S"). ${ }^{28}$ The Lords held that a straight bill of lading was to be viewed as a "bill of lading" within the meaning of art. I(b) of the Hague-Visby Rules and a straight bill of lading shared all the principal characteristics of a bill of lading except that it was only transferable to a named consignee. Lord Steyn summarised that one of the important characteristics of a bill of lading is a document of title to the goods which enables the consignee to take delivery of the goods at their destination or to dispose of them by the endorsement and delivery of the bill of lading. ${ }^{29}$

\section{B. The presentation rule in Carewins $v$ Bright Fortune}

The presentation rule under a straight bill of lading in The Brjj was overruled by the Hong Kong Court of Final Appeal in Carewins v. Bright Fortune in 2009. In this case, the carrier issued straight bills of lading to the shipper for the carriage of goods from Hong Kong to Los Angeles. On arrival in Los Angles, the carrier delivered the goods to the named consignee without presentation of the straight bills of lading and the consignee never paid for the goods. The shipper sued the carrier for breach of contract evidenced by the straight bills of lading. The straight bills of lading contained an attestation clause stating that "In witness whereof, the carrier by its agents has signed three (3) original Bill of Lading all of this tenor and date, one of which being accomplished the others to stand void."

In this case, all five judges of the Court of Final Appeal dismissed the appeal from the carrier. Ribeiro PJ gave the leading judgment in respect of the presentation rule under a straight bill of lading. In

\footnotetext{
${ }^{26}$ [2000] 1 Lloyd's Rep. 431 (C.F.I.).

${ }^{27}$ [2002] 2 Lloyd's Rep. 707 (C.A.).

${ }^{28}$ [2005] 1 Lloyd's Rep. 347.

${ }^{29}$ Id. at 357.
} 
the first place, Ribeiro PJ said that "there is no valid reason why the essential characteristic of a bill of lading as a document of title should depend on whether it is negotiable." He noted that it is true that a carrier is able to see who is the intended consignee on the face of the straight bill of lading, but that does not mean that he is justified in assuming that such person is entitled, as against the shipper, to possession of the goods. He further explained that "If the named consignee is unable to produce the bill of lading it may very well be because he has not paid for the goods and is not entitled to possession". 30 Secondly, in view of Ribeiro PJ, it is clear that the terms of the bills of lading issued in this case demonstrate a contractual intention that delivery should only be made against presentation of the original bills. If the parties had intended that there should be no need for production of the bill, they could easily have chosen to utilise a sea waybill. ${ }^{31}$

As to the attestation clause in the straight bills of lading in this case, Ribeiro PJ said that it "only makes sense in a context where the parties intend the bills to be presented to the carrier as the justification for release of the cargo to the holder of the bill". $\mathrm{He}$ also added that, "perhaps save in exceptional circumstances, the presentation rule would be an incident of the contract evidenced by a straight bill even if it contains no attestation clause." 32 Litton NPJ additionally commented that although the words "upon surrender" did not appear in the attestation clause and there were no express words requiring presentation of the bill against delivery, the words on the face of the document "one of which being accomplished" have the same effect. He also pointed out that such form of words had been used for a long time in bills of lading. ${ }^{33}$

Ribeiro PJ concluded that "as a matter of principle and in the light of persuasive authority, it is the law of Hong Kong that a carrier of goods shipped under a straight bill of lading is potentially liable for breach of contract or in conversion if it releases those goods without production of the original bill of lading", 34

\section{THE ROTTERDAM RULES’ PRESENTATION RULE AND SOLUTION}

The Rotterdam Rules were adopted by the UN General Assembly on December 11, 2008. The opening for signature of the Convention commenced on September 23, 2009 in Rotterdam, Netherlands. So far 22 countries have signed the Rotterdam Rules

\footnotetext{
See supra note 2 , at 420

31 Id. at 421.

${ }^{32} I d$. at 422-423.

${ }^{33} \mathrm{Id}$. at 437.

${ }^{34}$ Id. at 424.
} 
but not ratified the Rules. ${ }^{35}$ In the Rotterdam Rules, the delivery of goods and the presentation requirements are specified at length in chapter 9 .

\section{A. The presentation rule in the Rotterdam Rules}

The shipping documents are replaced by the concept "transport document" in the Rotterdam Rules. The transport document means a document issued under a contract of carriage by the carrier that evidences the receipt of goods under a contract of carriage and evidences or contains a contract of carriage. "Electronic transport record" also has been defined which has the same two functions to that of the transport document. ${ }^{37}$ The Rotterdam Rules divide the transport documents into non-negotiable and negotiable transport documents. However, whether a transport document is a document of title does not depend on the negotiability of it. A special kind of non-negotiable transport document, like a straight bill of lading as a document of title, is regulated in the Rotterdam Rules.

The presentation rule under these transport documents accordingly varies for the delivery of goods. The first circumstance is the delivery where no negotiable transport document or negotiable electronic transport record has been issued. The carrier shall deliver the goods to the person who has properly identified itself as the consignee on the request of the carrier. ${ }^{38}$ In the second circumstance where a non-negotiable transport document that requires surrender has been issued, the carrier shall deliver the goods to the consignee upon the consignee properly identifying itself and the surrender of the non-negotiable document. The carrier may refuse delivery if the person claiming to be the consignee fails to properly identify itself, and shall refuse delivery if the nonnegotiable document is not surrendered. If more than one original of such non-negotiable document have been issued, the surrender of one original will suffice and the other originals cease to have any effect or validity. ${ }^{39}$ Last, where a negotiable transport document or negotiable electronic transport record has been issued, the carrier shall deliver the goods to the holder of the document or the record

\footnotetext{
35 See Status 2008 - United Nations Convention on Contracts for the International Carriage of Goods Wholly or Partly by Sea - the "Rotterdam Rules", UNICITRAL, http://www.uncitral.org/uncitral/en/uncitral_texts/transport_goods/rotterdam_status.html (last visited Dec. 16, 2010).

${ }^{36}$ United Nations Convention on Contracts for the International Carriage of Goods Wholly or Partly by Sea $\S 1$, ๆ 14, opened for signature Sept. 23, 2009, G.A. Res. 63/122, U.N. Doc. A/RES/63/122 (Dec. 11, 2008) [hereinafter Rotterdam Rules]

37 Id. art. 1, 18.

38 Id. art. 45 (a).

39 Id. art. 46 (a).
} 
upon surrender of such document or upon demonstration by the holder that it is the holder of such record. If the holder is the shipper or the consignee of an order document or the person to which the document is duly endorsed, the holder shall also properly identify itself for the delivery purpose. The carrier shall refuse delivery if the aforesaid requirements are not satisfied. If more than one original of the document has been issued, and the number of originals is stated in that document, the surrender of one original will suffice and the other originals cease to have any effect or validity. When the record has been used, such record ceases to have any effect or validity upon delivery to the holder. ${ }^{40}$

\section{B. Comment on the presentation rule}

The new presentation rule adopted in the Rotterdam Rules generally follows the current practice of the shipping documents in the carriage of goods by sea. The provisions in respect of the electronic transport record aim to facilitate the application of electronic communication in shipping practice. Technically, it is confused about the difference of the wording "may" and "shall" emphasising the carrier's refusal of delivery in the circumstance where a non-negotiable transport document that requires surrender has been issued. They should have the same meaning and legal effect for the presentation purpose. Anyhow, it is a good attempt to unify the presentation rule for the delivery of goods in an international convention.

\section{Solution for China's problem}

The application of the right of control in the carriage of goods by sea in China to some extent deviates from the nature of the straight bill of lading. The carrier may be in a dilemma of delivery of goods. A solution is available in the Rotterdam Rules for China's problem. There is a similar right of control in the Rotterdam Rules which includes the right to obtain delivery of goods at a scheduled port of call and the right to replace the consignee by any other person. ${ }^{41}$ When the straight bill of lading as a document of title is issued, the shipper may exercise the right of control only by holding and presenting all the original straight bills of lading. Once one of or all the straight bills of lading has been transferred to the named consignee in the straight bills of lading, the shipper's right of control ceases to be in effect. ${ }^{42}$ Hence, only one party (either the shipper or

\footnotetext{
${ }^{40}$ Id. art. 47 , I 1.

${ }^{41} I d$. art. 50 , ๆ 1 .

${ }^{42} I d$. art. $51, \uparrow 2$ (b).
} 
the consignee) has the right to claim the delivery of the goods at the port of discharge. The conflict of the right concerning the delivery of goods between the shipper and the consignee under the straight bill of lading is avoided and the traditional presentation rule in China is accordingly preserved.

\section{CONCLUSION}

Influenced by the concept of the right of control in civil law, Provision 9 in the No.1 Judicial Interpretation of 2009 in China breaks the traditional presentation rule under the straight bill of lading. It differs from the legal recognition in Carewins $v$ Bright Fortune in Hong Kong where the presentation rule of a bill of lading still applies to the straight bill of lading. The carrier, if a dispute happens, may become the risk undertaker if cargo interests avoid the application of Provision 9 by forum shopping. On the other hand, given the application of Provision 9, the consignee in a straight bill of lading may lose protection if the shipper goes into liquidation. It may even result in marine fraud in international commercial transactions. The Rotterdam Rules are hoped to be a prescription for the harmony and the unification of the presentation rule of the straight bill of lading. 